This is an electronic reprint of the original article. This reprint may differ from the original in pagination and typographic detail.

Author(s): Ilander, Aki; Väisänen, Ari

Title: $\quad$ Control of matrix interferences by multiple linear regression models in the determination of arsenic and lead concentrations in fly ashes by inductively coupled plasma optical emission spectrometry

Year: $\quad 2010$

Version:

Please cite the original version:

Ilander, A. \& Väisänen, A. (2010). Control of matrix interferences by multiple linear regression models in the determination of arsenic and lead concentrations in fly ashes by inductively coupled plasma optical emission spectrometry. Journal of Analytical Atomic Spectrometry, (25), 1581-1587. doi:10.1039/c004191b

All material supplied via JYX is protected by copyright and other intellectual property rights, and duplication or sale of all or part of any of the repository collections is not permitted, except that material may be duplicated by you for your research use or educational purposes in electronic or print form. You must obtain permission for any other use. Electronic or print copies may not be offered, whether for sale or otherwise to anyone who is not an authorised user. 


\title{
Control of matrix interferences by multiple linear regression models in the determination of arsenic and lead concentrations in fly ashes by inductively coupled plasma optical emission spectrometry
}

\author{
Aki Ilander* and Ari Väisänen \\ ${ }_{5}$ Received (in $\left.X X X, X X X\right) X$ th $X X X X X X X X X 20 X X$, Accepted $X$ th $X X X X X X X X X 20 X X$ \\ First published on the web $X$ th $X X X X X X X X X 20 X X$
}

A multiple linear regression technique was used to evaluate and correct the matrix interferences in the determination of As and $\mathrm{Pb}$ concentrations in fly ashes by inductively coupled plasma optical 10 emission spectrometry. The direct determination of As and Pb in SRM 1633b by ICP-OES failed to obtain the certified concentrations, except in a couple of cases. However, it proved possible to use the multiple linear regression (MLR) technique to correct the determined concentrations to a satisfactory level. This method of correction is based on the multiple regression line obtained from the analysis of 19 synthetic mixtures of matrix and analyte elements (Al, As, $\mathrm{Ca}, \mathrm{Fe}, \mathrm{Pb}$, and $\mathrm{Si}$ ) at ${ }_{15}$ five levels of concentrations. The matrix interferences in the determination of As were caused by $\mathrm{Al}, \mathrm{Pb}$, and $\mathrm{Ca}$ whereas the matrix interferences in the determination of $\mathrm{Pb}$ were caused by $\mathrm{Al}$ and $\mathrm{Fe}$. The most suitable parameters for the determination of As and $\mathrm{Pb}$ were a plasma power of 1500 $\mathrm{W}$ and a nebulizer flow of 0.5 or $0.6 \mathrm{~L} \mathrm{~min}^{-1}$. The accuracy of the method was showed with the analysis of SRM 1633b and two fly ash samples with the standard addition method. A recovery 20 rate of $96 \%$ can be reached for $\mathrm{Pb}$ at $220.353 \mathrm{~nm}$ with three digestion methods (US-TSD, US1 and MW) by using both direct measurement with thoroughly optimized plasma conditions and the MLR method. A recovery rate of $93 \%$ was obtained for As when using the MLR method at $193.696 \mathrm{~nm}$ with the digestion method US2, a plasma power of $1500 \mathrm{~W}$, and nebulizer flow of $0.6 \mathrm{~L} \mathrm{~min}^{-1}$. The corrected and determined concentrations of $\mathrm{As}$ and $\mathrm{Pb}$ in samples analyzed resulted in a precision 25 of 0.6 to $3.9 \%$.

\section{Introduction}

The combustion of agricultural wastes, coal, municipal waste, peat and wood has generated huge amounts of different kinds of ashes during the previous decades ${ }^{1}$. Fly ashes contain 30 significant amounts of elements with a toxic character such as As, $\mathrm{Cd}, \mathrm{Co}, \mathrm{Cr}, \mathrm{Pb}, \mathrm{Ni}$, and $\mathrm{V}^{2,3}$. It is well known that those elements are potential risks in the environment even at low concentrations $^{3,4}$. A significant problem in the use of various kinds of fly ashes is the injurious effect on the environment 35 and human health ${ }^{5,6}$. Potential applications for fly ashes include construction materials (cement and ceramic), geotechnical structures (road pavement and embankments) and agriculture (soil amendment) ${ }^{1,7-9}$.

Microwave-accelerated digestion has become the most 40 commonly used sample pre-treatment method for the determination of toxic element concentrations in different kinds of solid samples by ICP-OES ${ }^{10-12}$. Microwave-assisted digestion can be performed in open or closed systems. Another practical sample pre-treatment method in the 45 determination of toxic element concentrations in solid samples is ultrasound-assisted digestion. Ultrasound-assisted digestion has been used for elemental analysis of many particulate materials such as contaminated soil, coal fly ash, biological samples and sediment ${ }^{13-16}$.

50 The methods used in the analysis of toxic elements in fly ash samples are based on atomic absorption or emission spectrometry together with a liquid sample introduction system. The main advantages of inductively coupled plasma optical emission spectrometry (ICP-OES) over atomic 55 absorption techniques are multi-element determination and high sample through-put with detection limits low enough for most of the analyte elements in fly ash samples ${ }^{17,18}$. The main emission lines for the determination of $\mathrm{Pb}$ are $217.000 \mathrm{~nm}$, $220.353 \mathrm{~nm}$ and $283.306 \mathrm{~nm}$. However, the most sensitive 60 emission line of $\mathrm{Pb}$ is $220.353 \mathrm{~nm}^{19}$. ICP-OES is used less than ICP-MS for the determination of As concentrations. However, As can be determined by ICP-OES. The main emission lines for the determination of As are $188.979 \mathrm{~nm}$ and $193.696 \mathrm{~nm}^{20,21}$. Interferences during sample introduction in 65 ICP-OES usually occur with samples of high viscosity and complex sample matrix. Most of the matrix effects are caused by the easily ionizable elements (EIEs) ${ }^{22,23}$. Anyway, several spectral interferences have been found in the determination of As and $\mathrm{Pb}$ by ICP-OES ${ }^{24}$. Direct spectral overlap interference 70 due to $\mathrm{Fe}$ was found when $\mathrm{Pb}$ was determined in the emission lines $217.000 \mathrm{~nm}$ and $283.306 \mathrm{~nm}^{24,25}$. Inter-element interference was found in the determination of $\mathrm{Pb}$ in the emission line $220.353 \mathrm{~nm}$ from $\mathrm{Al}$ and background shift was observed due to $\mathrm{Fe}^{19,24-27}$.

75 Evaluation and correction of matrix interferences in the ICP-OES measurements can be performed using the multiple linear regression technique $\mathrm{e}^{28-30}$. This technique is based on the 
Table 1 Calibration data of the determination of samples by ICP-OES

\begin{tabular}{|c|c|c|c|c|c|}
\hline Element & Wavelength nm & $\mathrm{r}$ & Atom/Ion I/II & $\mathrm{LOD}^{\mathrm{a}} \mathrm{mg} \mathrm{kg}^{-1}$ & Calibration range $\mathrm{mg} \mathrm{L}^{-1}$ \\
\hline \multicolumn{6}{|c|}{ Nebulizer flow $0.5 \mathrm{~L} \mathrm{~min}^{-1}$} \\
\hline As & 193.696 & 1.0000 & I & 5.9 & $0.1-10.0$ \\
\hline As & 188.979 & 1.0000 & I & 6.3 & $0.1-10.0$ \\
\hline $\mathrm{Pb}$ & 220.353 & 0.9999 & II & 6.4 & $0.1-10.0$ \\
\hline $\mathrm{Pb}$ & 217.000 & 1.0000 & I & 5.0 & $0.1-10.0$ \\
\hline \multicolumn{6}{|c|}{ Nebulizer flow $0.6 \mathrm{~L} \mathrm{~min}^{-1}$} \\
\hline As & 193.696 & 1.0000 & I & 4.7 & $0.1-10.0$ \\
\hline As & 188.979 & 0.9999 & I & 9.9 & $0.1-10.0$ \\
\hline $\mathrm{Pb}$ & 220.353 & 0.9999 & II & 4.9 & $0.1-10.0$ \\
\hline $\mathrm{Pb}$ & 217.000 & 0.9999 & I & 5.7 & $0.1-10.0$ \\
\hline
\end{tabular}

${ }^{\mathrm{a}} \mathrm{LOD}=$ limit of detection when $250 \mathrm{mg}$ sample was digested and filtrate diluted to a volume of $100 \mathrm{~mL}$. Calculated by substituting the intercept and its standard deviations multiplier $(a+3 s a)$ into the calibration line $y=b x+a^{32}$.

Bold $=$ wavelength selected for the final determination

analysis of synthetic mixtures of the matrix elements and the calculation of a multiple regression line for each element and wavelength analyzed ${ }^{31}$. The expression obtained for the regression line can be tested by correcting the concentrations 10 of matrix elements in both the synthetic mixtures and SRM sample. The significance of the differences between the corrected and the added or certified concentrations can subsequently be tested by significance tests such as the paired $t$-test ${ }^{32}$. Methods of this kind have successfully been used in 15 the analysis of fertilizers ${ }^{28}$, geological samples ${ }^{30}$, and soil samples $^{33}$.

The aim of this study was to develop an effective and precise method for the determination of $\mathrm{As}$, and $\mathrm{Pb}$ in power plant fly ashes by ICP-OES. The increasing demand for 20 accurate analysis of ashes is caused by increasing environmental concern about of fly ashes. The reuse potential of different kinds of ashes has been noticed worldwide.

\section{Experimental}

\section{Instrumentation}

25 All the measurements were performed with a Perkin-Elmer (Norwalk, CT, USA) model Optima 4300 DV inductively coupled plasma optical emission spectrometer. A Scott type double-pass spray chamber and a cross-flow nebulizer were used throughout. The determination of element concentrations 30 was performed with parameters of the instrument (nebulizer flow of 0.5 and $0.6 \mathrm{~L} \mathrm{~min}^{-1}$, auxiliary gas flow of $0.2 \mathrm{~L} \mathrm{~min}{ }^{-1}$, plasma gas flow of $15 \mathrm{~L} \mathrm{~min}^{-1}$ and plasma power of $1400 \mathrm{~W}$ and $1500 \mathrm{~W}$ ). Two wavelengths for both elements investigated were tested in axially viewed plasma. The appropriate 35 wavelengths used in the final determination are shown in Table 1.

\section{Reagents}

All the reagents used were of analytical grade and only high purity water of $18.2 \mathrm{M} \Omega \mathrm{cm}$ resistivity produced by a Maxima 40 water purification system supplied by Elga (Buckinghamshire, UK) was used throughout. Nitric acid (65 \%, p.a.) and hydrochloric acid (36-38 \%, p.a.) were supplied by Riedel-deHaën (Seelze, Germany) and hydrofluoric acid (40 \%, p.a.) was supplied by Merck (Darmstadt, Germany). The standard
45 stock solutions (1000 $\mathrm{mg} \mathrm{L}^{-1}$ ) for the ICP-OES measurements were supplied by Merck (Darmstadt, Germany). The working concentration ranges used are shown in Table 1.

Four standard stock solutions were prepared for the interference tests. Standard stock solutions of $\mathrm{Al}, \mathrm{Ca}$, and $\mathrm{Fe}$ 50 were prepared by dissolving appropriate amounts of $\mathrm{Al}\left(\mathrm{NO}_{3}\right)_{3}$ - $9 \mathrm{H}_{2} \mathrm{O}$ (р.a.), $\mathrm{Ca}\left(\mathrm{NO}_{3}\right)_{2} \cdot 4 \mathrm{H}_{2} \mathrm{O}$ (p.a.), or $\mathrm{Fe}\left(\mathrm{NO}_{3}\right)_{3} \cdot 9 \mathrm{H}_{2} \mathrm{O}$ (p.a.) in $50 \mathrm{~mL}$ of $2-10 \% \mathrm{HNO}_{3}$ and diluted to a volume of $250 \mathrm{~mL}$ with water; all three reagents were supplied by Merck (Darmstadt, Germany). The standard stock solution of $\mathrm{Si}$ 55 (1000 $\mathrm{mg} \mathrm{L}^{-1}$ ) was also supplied by Merck (Darmstadt, Germany).

\section{Samples}

A coal fly ash standard reference material, SRM $1633 \mathrm{~b}^{34}$, certified by the National Institute of Standards and 60 Technology (NIST) and two fly ash samples collected from wood burning plants were analyzed. All the fly ash samples were collected in Finland. Six replicate analyses of each fly ash sample were performed.

\section{Digestion procedures}

65 All four digestion procedures were performed with ultrasound or microwave methods. Those methods were presented with more details in our earlier studies ${ }^{15,35}$. Three digestion procedures were performed with an ultrasound method (USTSD, US1, and US2) and one digestion procedure was

70 performed with a microwave method standardized by the USEPA (MW).

1 US-TSD = Ultrasound (two-step): i) digestion solution of $6 \mathrm{~mL}$ of $\mathrm{HNO}_{3}$, (9 min) ii) digestion solution of $3 \mathrm{~mL}$ $\mathrm{HNO}_{3}$ and $3 \mathrm{~mL} \mathrm{HF}$, (18 min)

752 US1 = Ultrasound, digestion solution of $10 \mathrm{~mL}$ aqua regia and $0.5 \mathrm{~mL} \mathrm{HF}$, (18 min)

3 US2 = Ultrasound, digestion solution of $10 \mathrm{~mL}$ (1:1) aqua regia, (9 $\mathrm{min})$

$4 \mathrm{MW}=$ Microwave, digestion solution of $9 \mathrm{~mL} \mathrm{HNO}_{3}$ and 80 $3 \mathrm{~mL} \mathrm{HF}$, USEPA method 3052 
Table 2 Analytical results for two-step (US-TSD) digestion procedures in SRM 1633b (mean of six replicate samples, with the confidence limit of the mean, $P=0.05)$.

\begin{tabular}{ccccc}
\hline Results & As 188.979 nm mg kg-1 & Recovery \% & As 193.696 nm mg kg-1 & Recovery \% \\
\hline 1400 W: Neb 0.5 & $140.8 \pm 1.9$ & $103.4 \pm 1.4$ & $103.7 \pm 3.8$ & $76.1 \pm 2.8$ \\
1400 W: Neb 0.6 & $148.9 \pm 1.2$ & $109.3 \pm 0.9$ & $98.5 \pm 6.0$ & $72.3 \pm 4.5$ \\
1500 W: Neb 0.5 & $139.2 \pm 2.8$ & $102.2 \pm 2.1$ & $99.3 \pm 2.6$ & $72.9 \pm 2.0$ \\
1500 W: Neb 0.6 & $146.5 \pm 3.0$ & $107.6 \pm 2.3$ & $98.0 \pm 5.1$ & $72.0 \pm 3.8$ \\
Certified & $136.2 \pm 2.6$ & & $136.2 \pm 2.6$ & \\
\hline Results & Pb 217.000 nm mg kg-1 & Recovery \% & Pb 220.353 nm mg kg-1 & Recovery \% \\
\hline 1400 W: Neb 0.5 & $260.0 \pm 3.9$ & $381.2 \pm 5.8$ & $60.8 \pm 1.0$ & $99.1 \pm 1.5$ \\
1400 W: Neb 0.6 & $273.4 \pm 5.0$ & $400.9 \pm 7.4$ & $67.9 \pm 1.3$ & $91.5 \pm 1.2$ \\
1500 W: Neb 0.5 & $260.3 \pm 3.5$ & $381.7 \pm 5.2$ & $62.4 \pm 0.8$ & $98.2 \pm 0.9$ \\
1500 W: Neb 0.6 & $286.0 \pm 4.9$ & $419.4 \pm 7.2$ & $67.0 \pm 0.6$ & $68.2 \pm 1.1$ \\
Certified & $68.2 \pm 1.1$ & & &
\end{tabular}

\section{Results and discussion}

\section{${ }_{5}$ Calibration}

All concentration measurements were carried out using fourpoint calibration. As and $\mathrm{Pb}$ were determined by using two of the most sensitive emission lines to attain the sensitivity required. High values were obtained for the regression 10 correlation coefficients, as shown in Table 1.

Table 3 The added and the determined concentrations $\left(\mathrm{mg} \mathrm{L}^{-1}\right)$ of the synthetic mixtures of matrix elements with axial viewed plasma, plasma power of $1500 \mathrm{~W}$ and nebulizer flow of $0.6 \mathrm{~L} \mathrm{~min}^{-1}$.

\begin{tabular}{ccccccc}
\hline & Added & Found & Found & Added & Found & Found \\
& As & 188.979 & 193.696 & $\mathrm{~Pb}$ & 217.000 & 220.353 \\
\hline 1 & 0.50 & 0.771 & 0.474 & 0.40 & 0.332 & 0.413 \\
2 & 0.10 & 0.41 & 0.064 & 0.10 & 0.006 & 0.114 \\
3 & 0.40 & 0.435 & 0.382 & 0.10 & 0.311 & 0.108 \\
4 & 0.30 & 0.574 & 0.251 & 0.10 & 0.057 & 0.134 \\
5 & 0.40 & 0.655 & 0.321 & 0.25 & 0.395 & 0.242 \\
6 & 0.10 & 0.368 & 0.084 & 0.25 & 0.080 & 0.283 \\
7 & 0.10 & 0.134 & 0.078 & 0.70 & 0.960 & 0.653 \\
8 & 0.40 & 0.586 & 0.360 & 0.25 & 0.385 & 0.271 \\
9 & 0.10 & 0.328 & 0.030 & 0.40 & 0.793 & 0.361 \\
10 & 0.20 & 0.447 & 0.179 & 0.55 & 0.490 & 0.529 \\
11 & 0.50 & 0.695 & 0.413 & 0.40 & 0.797 & 0.372 \\
12 & 0.50 & 0.722 & 0.456 & 0.40 & 0.340 & 0.363 \\
13 & 0.20 & 0.213 & 0.187 & 0.10 & 0.362 & 0.135 \\
14 & 0.20 & 0.389 & 0.160 & 0.55 & 0.712 & 0.559 \\
15 & 0.30 & 0.522 & 0.259 & 0.55 & 0.632 & 0.491 \\
16 & 0.40 & 0.408 & 0.384 & 0.70 & 1.003 & 0.647 \\
17 & 0.30 & 0.524 & 0.286 & 0.70 & 0.507 & 0.659 \\
18 & 0.30 & 0.463 & 0.207 & 0.25 & 0.767 & 0.258 \\
19 & 0.20 & 0.422 & 0.153 & 0.70 & 1.060 & 0.640 \\
\hline
\end{tabular}

Concentration levels of matrix elements in synthetic mixtures:

$15 \mathrm{Al}=10-410 \mathrm{mg} \mathrm{L}^{-1}, \mathrm{Ca}=10-810 \mathrm{mg} \mathrm{L}^{-1}$,

$\mathrm{Fe}=5-305 \mathrm{mg} \mathrm{L}^{-1}, \mathrm{Si}=25-625 \mathrm{mg} \mathrm{L}^{-1}$

\section{Analysis}

The SRM 1633b was analyzed to test the validity of the procedure. The concentrations of the two elements (As, and
${ }_{20} \mathrm{~Pb}$ ) determined are shown in Table 2. Almost every measurement using different parameters of the determination of As and $\mathrm{Pb}$ in SRM 1633b by ICP-OES failed to obtain the certified concentrations, resulting in recoveries from 72 to 420 $\%$ (Table 2.). This was the case even if higher plasma power 25 and lower nebulizer flow was used instead of those recommended by the ICP-OES manufacturer. However, the precision of the concentrations determined by ICP-OES was quite similar with the certified concentrations.

Table 4 The results of the paired $t$-tests in evaluation of differences 30 between the added and the determined or corrected concentrations on the multiple regression line calculated from the analytical results of synthetic mixtures of the analyte elements.

\begin{tabular}{|c|c|c|c|c|}
\hline Parameters / Element & $\begin{array}{c}\text { As } \\
188.979 \\
\mathrm{~nm}\end{array}$ & $\begin{array}{c}\text { As } \\
193.696 \\
\mathrm{~nm}\end{array}$ & $\begin{array}{c}\mathrm{Pb} \\
217.000 \\
\mathrm{~nm}\end{array}$ & $\begin{array}{c}\mathrm{Pb} \\
220.353 \\
\mathrm{~nm} \\
\end{array}$ \\
\hline \multicolumn{5}{|l|}{ Added / Determined } \\
\hline \multicolumn{5}{|l|}{ Axial $1400 \mathrm{~W}$ : } \\
\hline Nebulizer $0.51 \mathrm{~min}^{-1}$ & 8.789 & 4.765 & 3.094 & 3.163 \\
\hline Nebulizer $0.61 \mathrm{~min}^{-1}$ & 9.193 & 4.111 & 4.365 & 1.046 \\
\hline \multicolumn{5}{|l|}{ Axial $1500 \mathrm{~W}$ : } \\
\hline Nebulizer $0.51 \mathrm{~min}^{-1}$ & 8.530 & 6.116 & 3.036 & 2.423 \\
\hline Nebulizer $0.61 \mathrm{~min}^{-1}$ & 8.658 & 7.002 & 2.758 & 1.503 \\
\hline \multicolumn{5}{|l|}{ Added / Corrected } \\
\hline \multicolumn{5}{|l|}{ Axial $1400 \mathrm{~W}$ : } \\
\hline Nebulizer $0.51 \mathrm{~min}^{-1}$ & 4.218 & 10.359 & 0.857 & 7.607 \\
\hline Nebulizer $0.61 \mathrm{~min}^{-1}$ & 3.194 & 1.077 & 8.592 & 12.923 \\
\hline \multicolumn{5}{|l|}{ Axial $1500 \mathrm{~W}$ : } \\
\hline Nebulizer $0.51 \mathrm{~min}^{-1}$ & 4.804 & 1.653 & 7.227 & 0.481 \\
\hline Nebulizer $0.61 \mathrm{~min}^{-1}$ & 3.584 & 2.001 & 2.169 & 1.590 \\
\hline$t_{\text {critical }(18)}=\mathbf{2 . 1 0}$ & & & & \\
\hline
\end{tabular}

$t_{\text {critical(18) }}=$ obtained from the $t$-distribution with the 18 degrees of freedom at the confidence level of $95 \%{ }^{32}$.

\section{${ }_{35}$ Evaluation of matrix interferences}

It is well known that fly ashes are very difficult to analyze, because their composition is unpredictable, highly variable, and also extremely heterogeneous. Evidently the sample matrices of the two fly ash samples and the SRM 1633b were 40 quite different. The interference caused by the elements in the synthetic mixtures on the analyte elements were next 
Table 5 Multiple linear regression data from the 19 synthetic mixtures of matrix elements.

\begin{tabular}{|c|c|c|}
\hline Element / parameters & Multiple linear regression expression & $\mathrm{R}$ \\
\hline \multicolumn{3}{|l|}{ As $188.979 \mathrm{~nm}$} \\
\hline $1400 \mathrm{~W}:$ Neb 0.5 & $+[0.93069 \mathrm{As}]-[0.0001844 \mathrm{Ca}]$ & 0.969 \\
\hline $1400 \mathrm{~W}$ : Neb 0.6 & $+[0.88128 \mathrm{As}]-[0.0001659 \mathrm{Ca}]$ & 0.979 \\
\hline $1500 \mathrm{~W}$ : Neb 0.5 & $+[0.97257 \mathrm{As}]-[0.0001298 \mathrm{Ca}]$ & 0.988 \\
\hline $1500 \mathrm{~W}$ : Neb 0.6 & $+[0.89014 \mathrm{As}]-[0.0002204 \mathrm{Ca}]$ & 0.975 \\
\hline \multicolumn{3}{|l|}{ As $193.696 \mathrm{~nm}$} \\
\hline $1400 \mathrm{~W}: \mathrm{Neb} 0.5$ & $+[0.9679 \mathrm{As}]-[0.05222 \mathrm{~Pb}]+[0.0000832 \mathrm{Al}]$ & 0.995 \\
\hline $1400 \mathrm{~W}$ : Neb 0.6 & $+[0.9432 \mathrm{As}]+[0.0000983 \mathrm{Al}]+[0.0000415 \mathrm{Ca}]$ & 0.996 \\
\hline $1500 \mathrm{~W}: \mathrm{Neb} 0.5$ & $+[1.01 \mathrm{As}]+[0.0001083 \mathrm{Al}]$ & 0.998 \\
\hline $1500 \mathrm{~W}$ : Neb 0.6 & $+[1.02 \mathrm{As}]+[0.0001443 \mathrm{Al}]$ & 0.999 \\
\hline \multicolumn{3}{|l|}{$\mathrm{Pb} 217.000 \mathrm{~nm}$} \\
\hline $1400 \mathrm{~W}$ : Neb 0.5 & $+0.1288+[0.9053 \mathrm{~Pb}]-[0.00121 \mathrm{Al}]+[0.000243 \mathrm{Ca}]-[0.000589 \mathrm{Fe}]$ & 0.979 \\
\hline $1400 \mathrm{~W}$ : Neb 0.6 & $+[0.8969 \mathrm{~Pb}]-[0.001473 \mathrm{Al}]+[0.000347 \mathrm{Ca}]-[0.000878 \mathrm{Fe}]$ & 0.985 \\
\hline $1500 \mathrm{~W}$ : Neb 0.5 & $+[0.9544 \mathrm{~Pb}]-[0.001383 \mathrm{Al}]+[0.000325 \mathrm{Ca}]-[0.000478 \mathrm{Fe}]$ & 0.989 \\
\hline $1500 \mathrm{~W}:$ Neb 0.6 & $+0.11927+[0.90366 \mathrm{~Pb}]-[0.0009468 \mathrm{Al}]+[0.0002948 \mathrm{Ca}]-[0.0009239 \mathrm{Fe}]$ & 0.983 \\
\hline \multicolumn{3}{|c|}{ 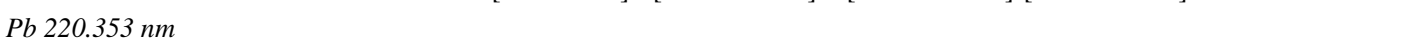 } \\
\hline $1400 \mathrm{~W}$ : Neb 0.5 & $+[1.084 \mathrm{~Pb}]+[0.0001044 \mathrm{Al}]-[0.0000752 \mathrm{Fe}]$ & 0.999 \\
\hline $1400 \mathrm{~W}$ : Neb 0.6 & $+[1.0985 \mathrm{~Pb}]+[0.0001088 \mathrm{Al}]$ & 0.997 \\
\hline $1500 \mathrm{~W}$ : Neb 0.5 & $-0.05528+[1.15 \mathrm{~Pb}]+[0.0001169 \mathrm{Al}]$ & 0.999 \\
\hline $1500 \mathrm{~W}$ : Neb 0.6 & $-0.052085+[1.14 \mathrm{~Pb}]+[0.0001046 \mathrm{Al}]-[0.00010182 \mathrm{Fe}]$ & 0.999 \\
\hline
\end{tabular}

evaluated by the multiple linear regression (MLR) method.

The interference caused by the matrix elements $\mathrm{Al}, \mathrm{Ca}, \mathrm{Fe}$, 5 and $\mathrm{Si}$ in the determination of $\mathrm{As}$ and $\mathrm{Pb}$ were studied in 19 synthetic mixtures (Table 3) of matrix elements at five concentrations. The concentrations were selected to include one level lower and one higher than those determined in SRM $1633 \mathrm{~b}$ and the real fly ash samples. The synthetic mixtures of 10 matrix elements were produced such that the matrix element concentrations did not correlate with each other. The interference effects were evaluated at wavelengths and parameters (plasma power and nebulizer flow) which had produced statistically unacceptable analyte concentrations 15 (Table 4). The calculations were carried out by selecting the added element concentrations and measured analyte concentrations as independent variables and the added analyte concentrations as a dependent variable. The calculations were performed using SigmaStat statistical software (Jandel 20 scientific). The multiple linear regression parameters calculated for $\mathrm{As}$ and $\mathrm{Pb}$ are shown in Table 5. Only statistically significant $(P<0.05)$ correction parameters were taken into consideration.

As can be seen in Table 5, Al, Ca, and Fe were the most 25 significant interfering elements in the sample matrix. Those elements may significantly affect analyte element concentrations because they usually occur at high concentrations in the sample matrix. According to the multiple linear regression data, the determination of As (both 30 wavelengths) using different measurement parameters yielded too high concentrations. Two exceptions were As at 193.696 $\mathrm{nm}$ with plasma power of $1500 \mathrm{~W}$ and nebulizer flow of $0.5 \mathrm{~L}$ $\min ^{-1}$ and $0.6 \mathrm{~L} \mathrm{~min}^{-1}$, which resulted in too low concentrations. Interference in the determination of As at $35188.979 \mathrm{~nm}$ was caused by Ca concentration in the matrix. Interference in the determination of As at $193.696 \mathrm{~nm}$ was mainly caused by $\mathrm{Al}$ (Table 5). When plasma power of
$1400 \mathrm{~W}$ was used the measurement of As was interfered also by $\mathrm{Ca}$ and $\mathrm{Pb}$. According to the MLR data the determination 40 of $\mathrm{Pb}$ at $217.000 \mathrm{~nm}$ resulted in too high concentrations, whereas the determination of $\mathrm{Pb}$ at $220.353 \mathrm{~nm}$ resulted in too low concentrations. Interference in the determination of $\mathrm{Pb}$ at $220.353 \mathrm{~nm}$ was caused by $\mathrm{Al}$, and Fe. The determination of $\mathrm{Pb}$ at $217.000 \mathrm{~nm}$ was enormously interfered by $\mathrm{Al}, \mathrm{Ca}$, and ${ }_{45} \mathrm{Fe}$ (Table 5). Due to this accurate determination of $\mathrm{Pb}$ at $217.000 \mathrm{~nm}$ cannot be performed.

According to M.G.A.Korn et. al. ${ }^{19}$, R.K. Winge et. $a{ }^{24}{ }^{24}$, P.W.J.M Boumans ${ }^{25}$, A. Asway et. al. ${ }^{27}$ and Iv. Boevski et. $a l .^{36}$, several spectral interferences have been found in the 50 determination of $\mathrm{As}$ and $\mathrm{Pb}$ by ICP-OES. The most commonly detected interfering elements are $\mathrm{Al}$ and $\mathrm{Fe}$ for the determination of $\mathrm{Pb}$ concentrations. Spectral overlap interference due to $\mathrm{Fe}$ and background interference due to $\mathrm{Al}$ and $\mathrm{Fe}$ were found in the determination of $\mathrm{Pb}$ in the emission 55 line $217.000 \mathrm{~nm}^{19,36}$. Inter-element interference from $\mathrm{Al}$ and background shift due to $\mathrm{Fe}$ have been found when $\mathrm{Pb}$ was determined in the emission line $220.353 \mathrm{~nm}^{19,36}$. According to A. Asway et. al. ${ }^{27}$, the determination of As at emission lines $188.979 \mathrm{~nm}$ and $193.696 \mathrm{~nm}$ was interfered by Fe, but that 60 interference could be corrected by a widely used background correction technique.

\section{Evaluation of wavelengths and determination parameters}

The correction was evaluated using wavelengths and measured parameters which produced statistically acceptable 65 analyte concentrations (Table 4). According to the paired $t$ tests, the correction of the As at $188.979 \mathrm{~nm}$ was not satisfactory because none of the tested parameters produced statistically acceptable analyte concentrations. However, it should be noted that the corrected mean concentration of As $70(188.979 \mathrm{~nm})$ approached the added mean concentration. As can been seen in Table 4, the correction of the As at 193.696 $\mathrm{nm}$ performed very well, because three of the tested 


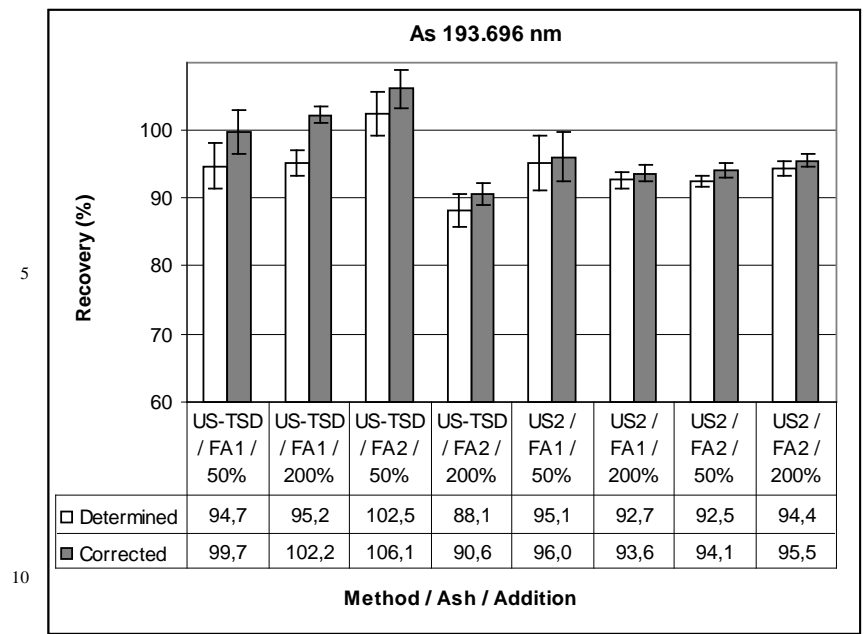

Fig. 1 Recovery rates of standard addition method in the determination of As with a plasma power $1500 \mathrm{~W}$ and nebulizer flow $0.5 \mathrm{~L} \mathrm{~min}^{-1}$. Precision of the method resulted in 15 1-4 \%.

parameters produced statistically acceptable analyte concentrations. The correction of the $\mathrm{Pb}$ at $217.000 \mathrm{~nm}$ did not perform well, because only one of the parameters tested produced statistically acceptable analyte concentrations, 20 whereas the correction of the $\mathrm{Pb}$ at $220.353 \mathrm{~nm}$ performed very well when plasma power of $1500 \mathrm{~W}$ was used. As can been seen in Table 5, the correlation coefficients of As $(193.696 \mathrm{~nm})$ and $\mathrm{Pb}(220.353 \mathrm{~nm})$ were higher than those for other wavelengths.

25 According to Tables 4 and 5, the most suitable wavelengths and determination parameters are As (193.696 nm) and $\mathrm{Pb}$ (220.353 nm), plasma power of $1500 \mathrm{~W}$ and nebulizer flow of $0.5 \mathrm{~L} \mathrm{~min}^{-1}$ or $0.6 \mathrm{~L} \mathrm{~min}^{-1}$. The concentrations of $\mathrm{As}$ and $\mathrm{Pb}$ determined using plasma power of $1500 \mathrm{~W}$ and nebulizer flow 30 of $0.5 \mathrm{~L} \mathrm{~min}^{-1}$ should be corrected using multiple linear regression; when plasma power of $1500 \mathrm{~W}$ and nebulizer flow of $0.6 \mathrm{~L} \mathrm{~min}{ }^{-1}$ was used, only the As concentrations needed correction.

According to M.G.A.Korn et. al. ${ }^{19}$, R.K. Winge et. al. ${ }^{24}$, 35 and Iv. Boevski et. al. ${ }^{36}$, the most suitable emission line for the determination of $\mathrm{Pb}$ is $220.353 \mathrm{~nm}$. According to A. Asfaw et. $a .^{27}$, typically used emission lines for the determination of As were all exposed to different types of spectral interference, but the most practical emission line for 40 the determination of As was $193.696 \mathrm{~nm}$ because the correction of that emission line can be easily done.

\section{Standard addition method}

The standard addition method was used to confirm the analysis of real fly ash samples in which the main matrix 45 element concentrations differed from the SRM 1633b. The standard addition method was performed in samples FA1 and FA2 using digestion methods US-TSD and US2 with a plasma power of $1500 \mathrm{~W}$ and nebulizer flow of $0.5 \mathrm{~L} \mathrm{~min}^{-1}$ and $0.6 \mathrm{~L}$ $\mathrm{min}^{-1}$. The concentrations of Ca were of about 5 to 15 -fold 50 higher in real fly ash samples than in the SRM sample, which may cause serious matrix interferences in ICP-OES. The standard addition method was performed at two levels of

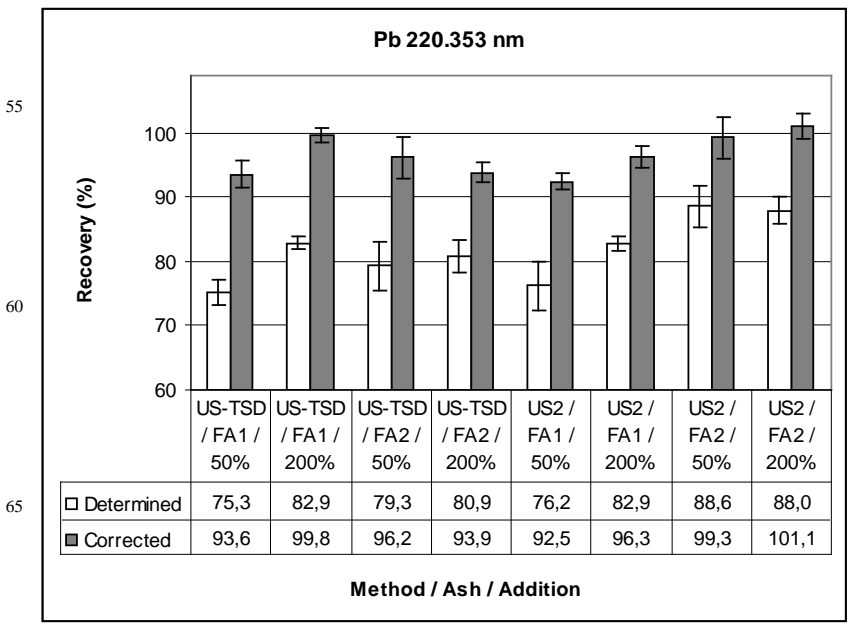

Fig. 2 Recovery rates of standard additotion method in the 70 determination of $\mathrm{Pb}$ with a plasma power $1500 \mathrm{~W}$ and nebulizer flow $0.5 \mathrm{~L} \mathrm{~min}^{-1}$. Precision of the method resulted in 1-3\%.

concentrations (50 \% and $200 \%$ addition) (Fig. 1 and Fig. 2). The standard addition method resulted in recovery rates from $7575 \%$ to $103 \%$ (determined), whereas standard addition with MLR method resulted in recovery rates from $90 \%$ to $106 \%$ (corrected). As can be seen in Fig. 1 and Fig. 2, the MLR correction was performed successfully in the determination of As and $\mathrm{Pb}$ in fly ash samples.

\section{MLR correction}

The MLR data of the matrix elements were used to correct the determined As, and Pb concentrations of SRM 1633b and two fly ash samples. The directly determined, corrected and certified concentrations of SRM 1633b with the recoveries are 85 shown in Table 6.

The MLR correction of the $\mathrm{Pb}$ concentrations (with plasma power of $1500 \mathrm{~W}$ and nebulizer flow of $0.5 \mathrm{~L} \mathrm{~min}^{-1}$ ) of the SRM was applied with great success in the digestion methods US-TSD and MW, resulting in recovery rates from $96.0 \%$ to $9097.6 \%$. On the other hand, the determination of the concentrations (with plasma power of $1500 \mathrm{~W}$ and nebulizer flow of $0.6 \mathrm{l} \mathrm{min}{ }^{-1}$ ) of the SRM for $\mathrm{Pb}$ was also quite successful in the digestion method US-TSD, US1 and MW, resulting in recovery rates from $96.9 \%$ to $98.3 \%$ (Table 6). ${ }_{95}$ The corrected concentrations of the SRM for $\mathrm{Pb}$ by the digestion method US2 was not successful, because the determined concentrations were lower than the quantification limit.

The corrected concentration of the SRM for As was not 100 successful because all results remained too low. The most suitable corrected concentrations of the SRM for As was obtained using the digestion method US2. The corrected As recoveries varied from $83.5 \%$ to $92.9 \%$ in the SRM sample. However, it should be noted that the corrected mean 105 concentration of As approached the certified value. The correction for the determined As concentrations of SRM 1633b was significantly higher in digestion methods US-TSD and US1 than digestion methods US2 and MW because their significant matrix element concentrations results were in even 
Table 6 The determined and corrected concentrations in four different digestion methods of the SRM 1633b based on the multiple regression line calculated from the analytical results at synthetic mixtures of matrix elements (mean of six replicate samples, with the confidence limit of the mean, $P=0.05$ ).

\begin{tabular}{|c|c|c|c|c|}
\hline Element / Results & Determined $\mathrm{mg} \mathrm{kg}^{-1}$ & Recovery \% & Corrected $\mathrm{mg} \mathrm{kg}^{-1}$ & Recovery \% \\
\hline \multicolumn{5}{|l|}{ As $193.696 \mathrm{~nm}$} \\
\hline \multicolumn{5}{|l|}{ Method: US-TSD } \\
\hline $1500 \mathrm{~W}:$ Neb 0.5 & $99.3 \pm 2.6$ & $72.9 \pm 2.0$ & $115.3 \pm 2.6$ & $84.7 \pm 2.0$ \\
\hline $1500 \mathrm{~W}$ : Neb 0.6 & $98.0 \pm 5.0$ & $72.0 \pm 3.8$ & $120.0 \pm 5.1$ & $88.1 \pm 3.8$ \\
\hline \multicolumn{5}{|l|}{ Method: US1 } \\
\hline $1500 \mathrm{~W}:$ Neb 0.5 & $103.0 \pm 2.4$ & $75.6 \pm 1.8$ & $115.2 \pm 2.2$ & $84.6 \pm 1.6$ \\
\hline $1500 \mathrm{~W}$ : Neb 0.6 & $96.5 \pm 4.2$ & $70.9 \pm 3.1$ & $113.7 \pm 4.7$ & $83.5 \pm 3.5$ \\
\hline \multicolumn{5}{|l|}{ Method: US2 } \\
\hline $1500 \mathrm{~W}:$ Neb 0.5 & $123.7 \pm 2.4$ & $90.8 \pm 1.8$ & $125.7 \pm 2.5$ & $92.3 \pm 1.7$ \\
\hline $1500 \mathrm{~W}$ : Neb 0.6 & $122.7 \pm 2.1$ & $90.1 \pm 1.5$ & $126.5 \pm 2.1$ & $92.9 \pm 1.6$ \\
\hline \multicolumn{5}{|l|}{ Method: MW } \\
\hline $1500 \mathrm{~W}:$ Neb 0.5 & $119.6 \pm 1.4$ & $87.8 \pm 1.1$ & $121.7 \pm 1.4$ & $89.4 \pm 1.0$ \\
\hline $1500 \mathrm{~W}$ : Neb 0.6 & $116.3 \pm 1.6$ & $85.4 \pm 1.2$ & $120.1 \pm 1.6$ & $88.2 \pm 1.2$ \\
\hline Certified & $136.2 \pm 2.6$ & & $136.2 \pm 2.6$ & \\
\hline \multicolumn{5}{|l|}{ Pb 220.353 nm } \\
\hline \multicolumn{5}{|l|}{ Method: US-TSD } \\
\hline $1500 \mathrm{~W}:$ Neb 0.5 & $62.4 \pm 0.8$ & $91.4 \pm 1.1$ & $66.5 \pm 0.7$ & $97.6 \pm 1.0$ \\
\hline $1500 \mathrm{~W}$ : Neb 0.6 & $67.0 \pm 0.6$ & $98.3 \pm 0.8$ & $63.9 \pm 0.4$ & $93.6 \pm 0.6$ \\
\hline \multicolumn{5}{|l|}{ Method: US1 } \\
\hline $1500 \mathrm{~W}:$ Neb 0.5 & $64.4 \pm 1.1$ & $94.4 \pm 1.6$ & $75.4 \pm 1.0$ & $110.5 \pm 1.5$ \\
\hline $1500 \mathrm{~W}$ : Neb 0.6 & $66.5 \pm 1.4$ & $97.6 \pm 2.1$ & $72.5 \pm 1.5$ & $106.3 \pm 2.1$ \\
\hline \multicolumn{5}{|l|}{ Method: US2 } \\
\hline $1500 \mathrm{~W}:$ Neb 0.5 & $<\mathrm{LOQ}$ & $<15 \%$ & $<\mathrm{LOQ}$ & $<15 \%$ \\
\hline 1500 W : Neb 0.6 & $<\mathrm{LOQ}$ & $<15 \%$ & $<\mathrm{LOQ}$ & $<15 \%$ \\
\hline \multicolumn{5}{|l|}{ Method: MW } \\
\hline $1500 \mathrm{~W}:$ Neb 0.5 & $65.3 \pm 0.5$ & $95.7 \pm 0.8$ & $65.5 \pm 0.7$ & $96.0 \pm 0.9$ \\
\hline $1500 \mathrm{~W}$ : Neb 0.6 & $66.1 \pm 1.2$ & $96.9 \pm 1.8$ & $62.9 \pm 1.4$ & $92.3 \pm 2.1$ \\
\hline Certified & $68.2 \pm 1.1$ & & $68.2 \pm 1.1$ & \\
\hline
\end{tabular}

US-TSD = Ultrasound (two-step): i) digestion solution of $6 \mathrm{~mL}$ of $\mathrm{HNO}_{3}, 9 \mathrm{~min}(3 \times 3 \mathrm{~min})$

$5 \quad$ ii) digestion solution of $3 \mathrm{~mL} \mathrm{HNO}_{3}$ and $3 \mathrm{~mL} \mathrm{HF}, 18 \mathrm{~min}(6 \times 3 \mathrm{~min})$

US1 = Ultrasound, digestion solution of $10 \mathrm{~mL}$ aqua regia and $0.5 \mathrm{~mL} \mathrm{HF}, 18 \mathrm{~min}(6 \times 3 \mathrm{~min})$

US2 = Ultrasound, digestion solution of $10 \mathrm{~mL}(1+1)$ aqua regia, $9 \mathrm{~min}(3 \times 3 \mathrm{~min})$

$\mathrm{MW}=$ Microwave, digestion solution of $9 \mathrm{~mL} \mathrm{HNO}_{3}$ and $3 \mathrm{~mL} \mathrm{HF}$, USEPA method 3052

10 15-fold higher. This is quite surprising because ultrasound method yielded significantly higher $\mathrm{Al}$ concentrations than microwave method with a mixture of $9 \mathrm{ml}$ of $\mathrm{HNO}_{3}$ and $3 \mathrm{ml}$ of $\mathrm{HF}$ as the digestion solution. The corrected concentrations of $\mathrm{As}$ and $\mathrm{Pb}$ in the SRM 1633b showed the same trend in 15 precision as in the certified concentrations.

The determined and corrected concentrations for four different digestion methods of two fly ash samples are presented in Table 7. The corrected concentrations of As for all real fly ash samples (FA1 and FA2) by four different 20 digestion methods were quite similar, almost every concentration being between $27-37 \mathrm{mg} \mathrm{kg}^{-1}$. The corrected concentrations of $\mathrm{Pb}$ for real fly ash samples were between 118 and $170 \mathrm{mg} \mathrm{kg}^{-1}$. The results were highly dependent on the digestion method used. The lowest concentrations of $\mathrm{Pb}$ 25 for all fly ash samples were obtained in the digestion method US2 with other digestion methods producing quite similar concentrations, as in the case of the SRM samples. The corrected concentrations of $\mathrm{As}$ and $\mathrm{Pb}$ depended on the matrix element concentrations in the fly ash samples with the same 30 kind of trend in corrections as in the analysis of the SRM 1633 b with only a few exceptions. The corrected and determined concentrations of $\mathrm{As}$ and $\mathrm{Pb}$ in real fly ash samples analyzed resulted in similar precision as those of the certified material (SRM 1633b). It should be noted that 35 slightly low concentrations of As in SRM 1633b may be due to loss of As during the digestion step. As can be seen in Fig. 1 , the standard addition method with MLR correction resulted in recovery rates from $93.6 \%$ to $106.1 \%$ for As in a case of real fly ash samples.

\section{${ }_{40}$ Conclusions}

Almost every direct determination of $\mathrm{As}$ and $\mathrm{Pb}$ concentrations in the SRM 1633b samples by using ICP-OES resulted in values that were too low. But then the analysis of $\mathrm{Pb}$ concentrations in SRM samples was successfully 45 performed by using the multiple linear regression technique, 
Table 7 The determined and corrected concentrations in four different digestion methods of two fly ash samples based on the multiple regression line calculated from the analytical results at synthetic mixtures of matrix elements (mean of six replicate samples, with the confidence limit of the mean, $P=0.05$ ).

\begin{tabular}{|c|c|c|c|c|}
\hline Element / Results & $\begin{array}{l}\text { As } 193.696 \mathrm{~nm} \\
\text { Determined } \mathrm{mg} \mathrm{kg}^{-1}\end{array}$ & Corrected $\mathrm{mg} \mathrm{kg}^{-1}$ & $\begin{array}{c}\mathrm{Pb} 220.353 \mathrm{~nm} \\
\text { Determined } \mathrm{mg} \mathrm{kg}^{-1}\end{array}$ & Corrected $\mathrm{mg} \mathrm{kg}^{-1}$ \\
\hline \multicolumn{5}{|l|}{ FA1 } \\
\hline \multicolumn{5}{|l|}{ Method: US-TSD } \\
\hline $1500 \mathrm{~W}:$ Neb 0.5 & $31.5 \pm 0.9$ & $34.5 \pm 1.4$ & $150.9 \pm 3.5$ & $154,8 \pm 3.6$ \\
\hline $1500 \mathrm{~W}$ : Neb 0.6 & $31.8 \pm 1.6$ & $36.3 \pm 1.3$ & $156.1 \pm 3.9$ & $157.2 \pm 3.9$ \\
\hline \multicolumn{5}{|l|}{ Method: US1 } \\
\hline $1500 \mathrm{~W}:$ Neb 0.5 & $29.2 \pm 2.1$ & $34.6 \pm 1.9$ & $137.4 \pm 1.1$ & $152.9 \pm 1.3$ \\
\hline $1500 \mathrm{~W}$ : Neb 0.6 & $27.3 \pm 1.7$ & $35.0 \pm 1.8$ & $136.9 \pm 1.8$ & $149.6 \pm 2.1$ \\
\hline \multicolumn{5}{|l|}{ Method: US2 } \\
\hline $1500 \mathrm{~W}:$ Neb 0.5 & $30.5 \pm 1.4$ & $34.1 \pm 1.4$ & $109.7 \pm 0.7$ & $118.9 \pm 0.8$ \\
\hline $1500 \mathrm{~W}$ : Neb 0.6 & $31.3 \pm 1.1$ & $36.4 \pm 1.1$ & $110.8 \pm 0.7$ & $118.6 \pm 0.7$ \\
\hline \multicolumn{5}{|l|}{ Method: MW } \\
\hline $1500 \mathrm{~W}:$ Neb 0.5 & $39.6 \pm 0.7$ & $40.4 \pm 0.7$ & $123.1 \pm 2.4$ & $131.4 \pm 2.8$ \\
\hline $1500 \mathrm{~W}$ : Neb 0.6 & $41.1 \pm 1.9$ & $42.7 \pm 1.9$ & $124.6 \pm 2.2$ & $132.4 \pm 2.5$ \\
\hline \multicolumn{5}{|l|}{ FA2 } \\
\hline \multicolumn{5}{|l|}{ Method: US-TSD } \\
\hline $1500 \mathrm{~W}:$ Neb 0.5 & $19.6 \pm 1.9$ & $24.9 \pm 1.9$ & $155.1 \pm 3.5$ & $162.9 \pm 3.9$ \\
\hline $1500 \mathrm{~W}:$ Neb 0.6 & $20.4 \pm 2.2$ & $27.8 \pm 2.3$ & $150.9 \pm 2.7$ & $149.3 \pm 3.6$ \\
\hline \multicolumn{5}{|l|}{ Method: US1 } \\
\hline $1500 \mathrm{~W}:$ Neb 0.5 & $22.6 \pm 1.8$ & $27.5 \pm 1.5$ & $139.9 \pm 2.8$ & $155.1 \pm 2.8$ \\
\hline $1500 \mathrm{~W}$ : Neb 0.6 & $20.3 \pm 1.6$ & $26.9 \pm 1.0$ & $135.1 \pm 3.0$ & $140.3 \pm 3.1$ \\
\hline \multicolumn{5}{|l|}{ Method: US2 } \\
\hline $1500 \mathrm{~W}:$ Neb 0.5 & $27.6 \pm 1.4$ & $30.3 \pm 1.4$ & $113.4 \pm 0.7$ & $122.4 \pm 0.9$ \\
\hline $1500 \mathrm{~W}$ : Neb 0.6 & $26.2 \pm 0.9$ & $30.1 \pm 0.9$ & $116.1 \pm 1.2$ & $120.3 \pm 1.4$ \\
\hline \multicolumn{5}{|l|}{ Method: MW } \\
\hline $1500 \mathrm{~W}$ : Neb 0.5 & $30.1 \pm 0.9$ & $31.9 \pm 0.9$ & $155.3 \pm 0.9$ & $169.4 \pm 1.0$ \\
\hline $1500 \mathrm{~W}:$ Neb 0.6 & $29.9 \pm 1.1$ & $32.5 \pm 1.1$ & $156.4 \pm 2.6$ & $164.4 \pm 2.8$ \\
\hline
\end{tabular}

US-TSD = Ultrasound (two-step): i) digestion solution of $6 \mathrm{~mL}$ of $\mathrm{HNO}_{3}, 9 \mathrm{~min}(3 \times 3 \mathrm{~min})$

$5 \quad$ ii) digestion solution of $3 \mathrm{~mL} \mathrm{HNO}_{3}$ and $3 \mathrm{~mL} \mathrm{HF}, 18 \mathrm{~min}(6 \times 3 \mathrm{~min})$

US1 = Ultrasound, digestion solution of $10 \mathrm{~mL}$ aqua regia and $0.5 \mathrm{~mL} \mathrm{HF}, 18 \mathrm{~min}(6 \times 3 \mathrm{~min})$

US2 = Ultrasound, digestion solution of $10 \mathrm{~mL}(1+1)$ aqua regia, $9 \mathrm{~min}(3 \times 3 \mathrm{~min})$

MW = Microwave, digestion solution of $9 \mathrm{~mL} \mathrm{HNO}_{3}$ and $3 \mathrm{~mL} \mathrm{HF}$, USEPA method 3052

10 whereas the corrected concentrations of the SRM for As were still too low. However, it should be noted that the corrected mean concentration of As approached the certified value resulting in a recovery of $92.9 \%$.

The results proved that it is possible to use the multiple 15 linear regression technique to evaluate matrix interferences in the determination of $\mathrm{As}$, and $\mathrm{Pb}$ in the fly ash samples by ICPOES. Only 19 synthetic mixtures of matrix elements were required to obtain reliable results. The matrix interferences in the determination of As were caused by $\mathrm{Al}, \mathrm{Pb}$, and $\mathrm{Ca}$ 20 whereas the matrix interferences in the determination of $\mathrm{Pb}$ were caused by $\mathrm{Al}$ and Fe. Similar interferences on the determination of $\mathrm{As}$ and $\mathrm{Pb}$ have been presented ${ }^{19,24,27}$; however, without the interference caused by Ca. In the case of the fly ash samples from wood combustion, the As and $\mathrm{Pb}$ 25 concentrations were dramatically interfered by $\mathrm{Ca}$ at wavelengths $188.979 \mathrm{~nm}$ and $217.000 \mathrm{~nm}$, respectively. The analysis showed that the sample matrix can strongly interfere with the determination of $\mathrm{As}$ and $\mathrm{Pb}$ causing significant changes in the determined element concentrations.

30 The most suitable wavelengths for the determination of As and $\mathrm{Pb}$ were $193.696 \mathrm{~nm}$ and $220.353 \mathrm{~nm}$, respectively. This is concordant with the observations presented in the literature ${ }^{24,27,36}$. The most suitable instrument parameters for the determination of $\mathrm{As}$ and $\mathrm{Pb}$ were plasma power of $1500 \mathrm{~W}$ 35 and nebulizer flow of $0.5 \mathrm{~L} \mathrm{~min}^{-1}$ or $0.6 \mathrm{~L} \mathrm{~min}{ }^{-1}$. The determination of $\mathrm{As}$ and $\mathrm{Pb}$ using plasma power of $1500 \mathrm{~W}$ and nebulizer flow of $0.5 \mathrm{~L} \mathrm{~min}^{-1}$ resulted in concentrations that must be corrected using multiple linear regression. The determination of $\mathrm{As}$ and $\mathrm{Pb}$ with plasma power of $1500 \mathrm{~W}$ and 40 nebulizer flow of $0.6 \mathrm{~L} \mathrm{~min}^{-1}$ resulted in concentrations where only As had to be corrected by the MLR technique. It is well known that the accurate determination of toxic elements such as $\mathrm{As}$ and $\mathrm{Pb}$ are crucial in cases of suspected environmental and health risks. 


\section{Notes and references}

Department of Chemistry, University of Jyväskylä,P.O. Box 35, FIN40014 Jyväskylä, Finland. Fax: +358 14260 2501; Tel: +358 14260 2613; E-mail: aki.ilander@jyu.fi

1 L. Reijnders, Resour. Conserv. Recycl., 2005, 43, 313.

2 O. Hjelmar, J. Hazard. Mater.,1996, 47, 345.

3 M. Izquierdo, X. Querol, J. Davidovits, D. Antenucci, H. Nugteren, C. Fernández-Pereira, J. Hazard. Mater., 2009, 166, 561.

104 L. Ebdon, L. Pitts, R. Cornelis, H. Crews, O.F.X. Donald, Ph. Quevauviller, Trace Element Speciation for Environment, Food and Health, RSC. MPG Books Ltd, Bodmin, Cornwall, UK, 2001.

5 T. Sabbas, A.Polettini, S. R. Pomi, T. Astrup, O. Hjelmar, P. Mostbauer, G. Cappai, G. Magel, S. Salhofera, C. Speiser, S. HeussAssbichler, R. Klein, P. Lechner, Waste Manage., 2003, 23, 61.

6 S. V. Vassilev, C. G. Vasileva, Fuel, 2007, 86, 1490.

7 R. Kumar, S. Kumar, S.P. Mehrotra, Resour. Conserv. Recycl., 2007, 52, 157.

8 R. Rajamma, R. J. Ball, L. A. C. Tarelho, G. C. Allen, J. A.

$20 \quad$ Labrincha, V. M. Ferreira, J. Hazard. Mater., 2009, 172, 1049.

9 L. Reijnders, Build. Environ., 2007, 42, 1036.

10 H. M. Kingston, L. B. Jassie, Introduction to Microwave Sample Preparation: Theory and Practice, American Chemical Society, Washington D.C., 1988.

2511 K. Lamble, S. Hill, Analyst, 1998, 123, 103R.

12 K. Srogi, Analytical Letters, 2007, 40, 199.

13 T. J. Mason, Sonochemistry: The Uses of Ultrasound in Chemistry, The Royal Society of Chemistry, Cambridge, 1990.

14 D. Hristozov, C.E. Domini, V. Kmetov, V. Stefanova, D. Georgieva, A. Canals, Anal. Chim. Acta, 2004, 516, 187.

15 A. Ilander, A. Väisänen, Anal. Chim. Acta, 2007, 602, 195.

16 F. Priego-Capote, M.D. Luque de Castro, J. Biochem. Biophys. Methods, 2007, 70, 299.

17 J. Nölte, ICP Emission Spectrometry, A Practical Guide, Wiley-VCH, Weinheim, 2003.

18 A. Iwashita, T. Nakajima, H. Takanashi, A. Ohki, Y. Fujita, T. Yamashita, Talanta , 2007, 71, 251.

19 M. G. A. Korn, J.B. de Andrade, D. S. de Jesus, V. A. Lemos, M. L. S. F. Bandeira, W. N. .L. dos Santos, M. A. Bezerra, F. A. C. Amorim, A.

40 S. Suoza, S. .L. C. Ferreira, Talanta, 2006, 69, 16.

20 PerkinElmer, Optima Simultaneous Spectrometers, Wavelength Tables, PerkinElmer inc. Connecticut, USA, 2001.

21 D. Q. Hung, O. Nekrassova, R.. G. Compton, Talanta, 2004, 64, 269.

22 J-L. Todoli, J-M. Mermet, Spectrochim. Acta, Part B, 1999, 54, 895.

4523 N. Daskalova, Iv. Boevski, Spectrochim. Acta, Part B, 1999, 54, 1099.

24 R. K Winge, V. A. Fassel, V. J. Peterson, M. A. Floyd, Inductively Coupled Plasma-Atomic Emission Spectroscopy: An Atlas of Spectral Information, Elsevier, Amsterdam, 1985.

25 P. W. J. M. Boumans, Inductively Coupled Plasma Emission

50 Spectroscopy, Part I, Methodology, Instrumentation, and performance, Chemical Analysis Vol. 90., Wiley \& Sons, New York, 1987.

26 M. Stepan, P. Musil, E. Poussel, J. M. Mermet, Spectrochim. Acta, Part B 2001, 56, 443.

5527 A. Asfaw, G. Wibetoe, Spectrochim. Acta, Part B 2009, 64, 363.

28 R. Matilainen, J. Tummavuori, J. AOAC Int., 1996, 79, 22.

29 T. Piippanen, J. Rautiainen, J. Tummavuori, Anal. Chim. Acta, 1997, 349, 327.

30 A. Väisänen, R. Matilainen, J. Tummavuori, Fresenius` J. Anal. Chem., 2000, 367, 755.

31 E. Fox, K. Shotton and C. Ulrich, SigmaStat statistical software - User`s manual. version 2.0, Jandel Corporation, 1995.

32 J. N. Miller, J. C. Miller, Statistics and Chemometrics for Analytical Chemistry, $4^{\text {th }}$ edition, Pearson Education Limited, Dorchester, 2000.

6533 A. Väisänen, A. Ilander, Anal. Chim. Acta, 2006, 570, 93.

34 T.E. Gills, Certificate of Analysis, Standard Reference Material 1633b, National Institute of Standards and Technology, Gaithersburg, 1993.

35 A. Ilander, A. Väisänen, Ultrasonics Sonochemistry, 2009, 16, 763.
7036 Iv. Boevski, N. Daskalova, I Havezov, Spectrochim. Acta, Part B, 2000, 55, 1643. 